\begin{tabular}{|c|c|c|}
\hline$\exists$ & International Journal of Current Research in & \\
\hline & $\begin{array}{c}\text { Biosciences and Plant Biology } \\
\text { ISSN: 2349-8080 (Online) } \bullet \text { Volume } 3 \bullet \text { Number } 3 \text { (March-2016) }\end{array}$ & \\
\hline $\begin{array}{l}\text { EXCELLENT } \\
\text { PUBLISHERS }\end{array}$ & Journal homepage: www.ijcrbp.com & 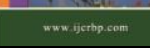 \\
\hline
\end{tabular}

\title{
Effect of Plant Growth Regulators on Callus Induction in Atalantia monophylla and Pamburus missionis
}

\author{
S. Jaya Sree ${ }^{*}$, N. Vijayakumar² and K. Suseela Gomathi ${ }^{3}$ \\ ${ }^{1}$ Department of Botany and Research Centre, S.T. Hindu College, Nagercoil- 629 oo2, Tamilnadu, India \\ ${ }^{2}$ Department of Botany and Research Centre, S. T. Hindu College, Nagercoil- 629 002, Tamilnadu, India \\ 3Department of Biotechnology, Malankara Catholic College, Mariagiri, Kaliakkavilai- 629 153, Tamilnadu, India \\ *Corresponding author.
}

\begin{abstract}
A b s tract
The effects of plant growth regulators on callus induction were studied in two plants such as Atalantia monophylla and Pamburus missionis. Different concentrations and combinations of hormones were used in MS medium to observe callus induction using leaf as explant. The rate of callus formation varied in different treatments used. The high percentage response of callus induction $(90.6 \pm 1.15 \%)$ was produced on MS medium containing 2,4-D $(5 \mathrm{mg} / \mathrm{l})$ from leaf after 17 days in A. monophylla leaf. In case of combination effect of MS media with plant growth hormone $(0.25,0.5,1 \mathrm{mg} / \mathrm{l}$ of IAA and BA), $(0.25,0.5,1 \mathrm{mg} / 1$ of 2,4-D and BA) showed no response in A. monophylla. In P. missionis leaf, high percentage response $93.4 \pm 1.50 \%$ was produced on MS medium containing $5 \mathrm{mg} / \mathrm{ml}$ 2,4-D after 29 days. Among the tested plant growth regulators, MS media supplemented with varying concentration of 2,4-D showed best response for callus induction in A. monophylla and P. missionis leaf explant.
\end{abstract}

\section{Introduction}

Tissue culture methods are recognized as excellent tools for medicinal plant propagation, allowing the production of pathogen-free plants, under controlled conditions and with independence of climatic factors. In vitro culture techniques offer a viable tool for mass multiplication and germplasm conservation of rare, endangered and threatened medicinal plants (Sahoo and Chand, 1998). Plants generate unorganized cell masses, such as callus or tumors, in response to stresses, such as wounding or pathogen infection. Callus formation in debarked trees was described over 200 years ago (Neely, 1979). The term "callus" originates from the Latin word callum, which means hard, and in medicine it refers to the thickening of dermal tissue. The disorganized cell masses are collectively called callus. Callus can be produced from a single differentiated cell, and many callus cells are

\section{Article Info}

Accepted: 18 February 2016

Available Online: 06 March 2016

\section{Ke ywords}

Atalantia monophylla

Callus

Growth hormone

Pamburus missionis

Percentage response totipotent, being able to regenerate the whole plant body (Steward et al., 1958; Nagata and Takebe, 1971). Callus has been widely used in both basic research and industrial applications (George and Sherrington, 1984; Bourgaud et al., 2001). The two plants used in the study include $A$. monophylla and P. missionis. A. monophylla is a small, branched shrub with rounded twigs. $P$. missionis is a small tree with a round, branching bushy head. Both plants belong to Rutaceae family. The main aim and objectives of the present study is to evaluate the effect of growth regulators on callus induction using leaf as explants.

\section{Materials and methods}

\section{Plant material}

Healthy plants were first selected for the tissue culture work. Shoot with young leaves was collected from the 
healthy plants. The leaves of $A$. monophylla and $P$. missionis plants were used as the explant. For the surface sterilization, the explants were washed thoroughly in running tap water for 30 minutes. The explants were again washed with liquid detergent for 10 minutes with vigorous shaking. Then it was again washed with running tap water to remove any traces of detergent for 30 minutes. Explant was then treated with $20 \%$ sodium hypochlorite solution for 5-10 minutes. In a sterile laminar airflow hood, decant the chemical sterilant and wash the explant thoroughly 3-5 times with sterile distilled water.

\section{Culture media}

The basal medium used for the culture is MS (Murashige and Skoog medium) (Murashige and Skoog, 1962) with sucrose $30 \mathrm{~g}$ (Analytical grade, Himedia, India), $8 \mathrm{~g}$ agar and growth hormones. 2,4-Dichlorophenoxy acetic acid (2,4-D), Benzyl adenine (BA), Indole-3 acetic acid (IAA) were added to the basal medium either singly or in various combinations. The medium was prepared by adding required quantities of all the ingredients in the conical flask. After adding all the ingredients in required amounts, the final volume is made with distilled water. The $\mathrm{pH}$ of the medium was adjusted to 5.8 by drop-wise addition of $1 \mathrm{~N} \mathrm{KOH}$ or $1 \mathrm{~N} \mathrm{HCl}$. After adjusting the $\mathrm{pH}$, agar 6-8 g/l was added to the medium for solidification. The solution was heated while stirring until the agar was dissolved. The heated medium was poured in glass bottles, tightly capped and labeled properly. The culture medium was sterilized in an autoclave for 20 minutes at $121^{\circ} \mathrm{C}$ at 15 psi.

\section{Inoculation of explants for callus induction}

After surface sterilization, explants were inoculated in culture bottles aseptically. For inoculation explants were transferred to sterile glass Petriplate with the help of sterile forceps under aseptic conditions. Here the explants were cut into suitable sizes approximately $1 \mathrm{~cm}^{2}$ sections with sterile scalpel and inoculated on the following medium. Explants are inoculated into the culture bottles containing following medium: MS medium with $0.25,0.5,1.0,2.0,3.0,4.0,5.0 \mathrm{mg} / 1$ 2,4-D; MS medium with $0.25,0.5,1.0 \mathrm{mg} / \mathrm{l} \mathrm{IAA}$, MS medium with $0.25,0.5,1.0 \mathrm{mg} / \mathrm{l}, \mathrm{IAA}+0.25,0.5,1.0 \mathrm{mg} / \mathrm{l} \mathrm{BA}$; MS medium with $0.25,0.5,1.0 \mathrm{mg} / \mathrm{l} 2,4-\mathrm{D}+0.25,0.5$, $1.0 \mathrm{mg} / \mathrm{l} \mathrm{BA}$. Each treatment consisted of ten replicates and was repeated three times. After inoculation, the mouth of the culture bottle is quick flamed, tightly capped and properly sealed with klin film to avoid entry of external air. The bottles were transferred to tissue culture room. All cultures were incubated under $16 \mathrm{hrs}$ photoperiod with light intensity of 1200 lux and temperature of $25 \pm 2{ }^{\circ} \mathrm{C}$. All cultures were monitored weekly. The percentage of explants produced callus and day of callus formed were observed. The colour of the callus was also recorded. Callus tissue induced were cut into small pieces approximately $0.5 \mathrm{~cm}^{2}$ and subcultured on the same callus induction medium for proliferation.

\section{Results and discussion}

\section{Callus induction of $A$. monophylla leaf explant}

Callus induction was carried out using leaf of $A$. monophylla as explants. In order to establish the most suitable concentrations of plant growth regulators for callus induction, various concentrations and combinations of the plant hormones 2,4-D, IAA and BA were tested in the present study. Table 1 shows the percentage response of callus induction and the number of days taken for callusing in MS medium supplemented with different concentration of plant growth hormones. The best result in terms of percentage response of callus induction $(90.6 \pm 1.15 \%)$ and other favorable characteristics were obtained on the MS medium supplemented with 2,4-D (5 mg/l). This treatment did not result in browning of the callus which was yellowish white in colour (Fig. 1).

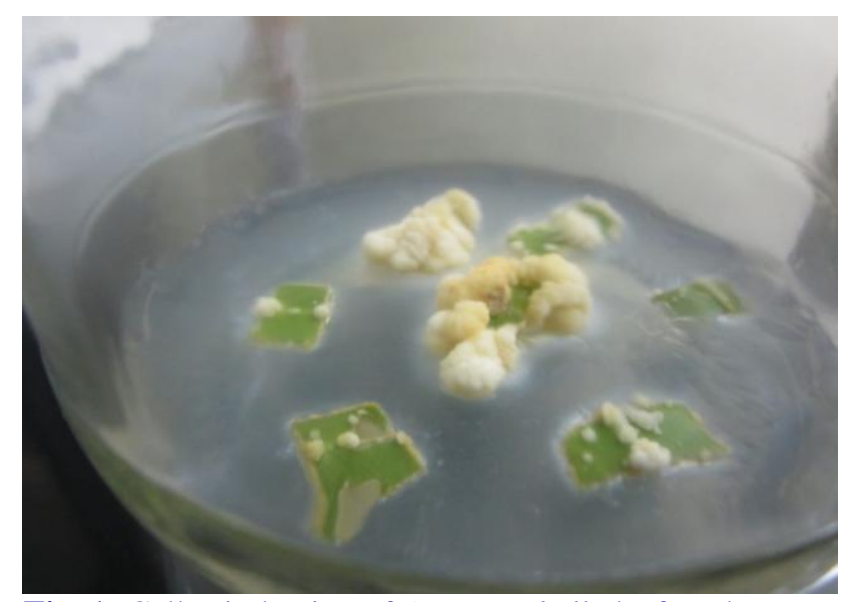

Fig. 1: Callus induction of A. monophylla leaf explant.

The initiation of the callus was noted within a short incubation period of 17 days. Among the different concentration of 2,4-D, $0.5 \mathrm{mg} / \mathrm{l}$ showed low response $(60.3 \pm 2.51 \%)$ within 27 days of incubation. Other concentration of 2,4-D showed moderate response. MS medium supplemented with IAA $(1 \mathrm{mg} / \mathrm{l})$ showed $20.6 \pm$ $0.57 \%$ callus induction response within 30 days. In case 
of combination effect of MS media with plant growth hormone $(0.25,0.5,1 \mathrm{mg} / \mathrm{l}$ of IAA and BA), $(0.25,0.5,1$ $\mathrm{mg} / \mathrm{l}$ of 2,4-D and BA) showed no response. It has been found that increase in concentration of 2,4-D resulted in increase in percentage response. Among the tested plant growth hormones, MS media supplemented with varying concentration of 2,4-D showed best response for callus induction in A. monophylla leaf explant. These results are in conformity with some of the earlier studies on different Rutaceae, which showed good callus induction response under the influence 2,4-D in combination with other phytohormone (Savita Singh et al., 2011; Singh et al., 2011). Pandey et al. (1994) who worked with rice found that callusing in seeds was best when $2 \mathrm{mg} / \mathrm{L} \mathrm{2,4-}$ $\mathrm{D}$ was supplemented. The usefulness of 2,4-D for callus growth has been verified for wheat (Abdrabou and Moustafa, 1993). These results are also supported by Barabanova et al. (1988), who achieved callus induction on winter wheat using culture medium containing 1.5 $\mathrm{mg} / \mathrm{L}$ 2,4-D. According to Rashid et al. (2009), the addition of $2 \mathrm{mg} / \mathrm{L}$ of 2,4-D was the most effective for callus induction where $97.18 \%$ callus development was observed in T. aestivum cv. tatara. Bartok and Sagi (1990), on the other hand, were successful in using higher concentrations of 2,4-D (6.0-8.0 mg/L), a contrast to the low concentrations.

Table 1. Callus induction in A. monophylla leaf explant using MS media supplemented with different concentrations of growth hormones.

\begin{tabular}{|c|c|c|c|c|c|c|}
\hline \multirow{2}{*}{$\begin{array}{l}\text { Sl. } \\
\text { No }\end{array}$} & \multicolumn{3}{|c|}{$\begin{array}{l}\text { Concentration of growth hormone } \\
(\mathrm{mg} / \mathrm{l})\end{array}$} & \multirow{2}{*}{$\begin{array}{l}\text { Percentage of } \\
\text { response }(\%)\end{array}$} & \multirow{2}{*}{$\begin{array}{l}\text { Number of days taken } \\
\text { for callus induction }\end{array}$} & \multirow{2}{*}{ Callus morphology } \\
\hline & 2,4-D & IAA & $\mathbf{B A}$ & & & \\
\hline 1 & 0.25 & - & - & 0 & - & - \\
\hline 2 & 0.5 & - & - & $60.3 \pm 2.51$ & 27 & Yellowish white \\
\hline 3 & 1 & - & - & $63.1 \pm 0.76$ & 23 & Yellowish white \\
\hline 4 & 2 & - & - & $64.5 \pm 1.80$ & 21 & Yellowish white \\
\hline 5 & 3 & - & - & $76.6 \pm 1.52$ & 20 & Yellowish white \\
\hline 6 & 4 & - & - & $86.3 \pm 2.05$ & 20 & Yellowish white \\
\hline 7 & 5 & - & - & $90.6 \pm 1.15$ & 17 & Yellowish white \\
\hline 8 & - & 0.25 & - & 0 & - & - \\
\hline 9 & - & 0.5 & - & 0 & - & - \\
\hline 10 & - & 1 & - & $20.6 \pm 0.57$ & 30 & Yellowish white \\
\hline 11 & - & 0.25 & 0.25 & 0 & - & - \\
\hline 12 & - & 0.5 & 0.5 & 0 & - & - \\
\hline 13 & - & 1 & 1 & 0 & - & - \\
\hline 14 & 0.25 & - & 0.25 & 0 & - & - \\
\hline 15 & 0.5 & - & 0.5 & 0 & - & - \\
\hline 16 & 1 & - & 1 & 0 & - & - \\
\hline
\end{tabular}

\section{Callus induction of $\boldsymbol{P}$. missionis leaf explant}

Callus induction was carried out using leaf of P. missionis as explants on MS medium supplemented with varying concentration of different growth hormones namely, 2,4-D, BA, IAA. Callus induction was experimented by providing a broad range of growth hormone combination using 3 different growth hormones with varying concentration. Among these hormones, 5 $\mathrm{mg} / \mathrm{l}$ 2,4-D concentration showed the good callus development rating $(93.4 \pm 1.50 \%)$ and the initiation of the callus in this combination was noted within a incubation period of 29 days. In case of $2,4-\mathrm{D}+\mathrm{BA}$ supplemented media, the medium with 2,4-D $(1 \mathrm{mg} / \mathrm{l})+$ BA $(1 \mathrm{mg} / \mathrm{l})$ showed $50.3 \pm 1.52 \%$ callus induction response after 36 days of inoculation. It has been found that increase in concentration of plant growth hormone resulted in increase in the percentage response of callus formation. Among the three concentrations of growth hormones, 2,4-D showed most favorable results in terms of percentage response of callus formed. This fast induction of callus by the selected growth hormone provides a valid tool for mass multiplication in P. missionis. 
MS media supplemented in combination with BA and IAA showed moderate response $(63.8 \pm 1.19 \%)$ within short incubation period of 19 days. The percentage response, number of days taken for callus induction and its morphology was displayed in Table 2 and Fig. 2. This was the first in vitro culture report of $P$. missionis for callus induction using leaf as explants. The results of Shah et al. (2003) showed that excellent callus was induced in wheat by using $3.5 \mathrm{mg} / \mathrm{L} \mathrm{2,4-D} \mathrm{and} \mathrm{good} \mathrm{callus} \mathrm{induction} \mathrm{was}$ obtained with $3 \mathrm{mg} / \mathrm{L}$. According to Haliloglu (2006), MS medium supplemented with $2 \mathrm{mg} / \mathrm{L} 2,4-\mathrm{D}$ produced $96 \%$ embryogenic callus in wheat.

Table 2: Callus induction in P. missionis leaf explant using MS media supplemented with different concentrations of growth hormones.

\begin{tabular}{|c|c|c|c|c|c|c|}
\hline \multirow{2}{*}{$\begin{array}{l}\text { Sl. } \\
\text { No }\end{array}$} & \multicolumn{3}{|c|}{$\begin{array}{l}\text { Concentration of growth hormone } \\
(\mathrm{mg} / \mathrm{l})\end{array}$} & \multirow{2}{*}{$\begin{array}{l}\text { Percentage of } \\
\text { response }(\%)\end{array}$} & \multirow{2}{*}{$\begin{array}{l}\text { Number of days taken } \\
\text { for callus induction }\end{array}$} & \multirow[t]{2}{*}{ Callus morphology } \\
\hline & 2,4-D & IAA & BA & & & \\
\hline 1 & 0.25 & - & - & 0 & - & - \\
\hline 2 & 0.5 & - & - & 0 & - & - \\
\hline 3 & 1 & - & - & $37.8 \pm 2.02$ & 36 & Whitish creamy \\
\hline 4 & 2 & - & - & $76.3 \pm 1.52$ & 35 & Whitish creamy \\
\hline 5 & 3 & - & - & $75.3 \pm 2.51$ & 35 & Whitish creamy \\
\hline 6 & 4 & - & - & $87.2 \pm 1.36$ & 32 & Whitish creamy \\
\hline 7 & 5 & - & - & $93.4 \pm 1.50$ & 29 & Whitish creamy \\
\hline 8 & 0.25 & 0.25 & - & 0 & - & - \\
\hline 9 & 0.5 & 0.5 & - & 0 & - & - \\
\hline 10 & 1 & 0.5 & & $45.3 \pm 3.51$ & 38 & Whitish creamy \\
\hline 11 & 1 & 1 & - & $50.3 \pm 1.52$ & 36 & Whitish creamy \\
\hline 12 & - & 0.25 & 0.25 & 0 & - & - \\
\hline 13 & - & 0.5 & 0.5 & 0 & - & - \\
\hline 14 & - & 1 & 1 & $63.8 \pm 1.19$ & 19 & Whitish creamy \\
\hline
\end{tabular}

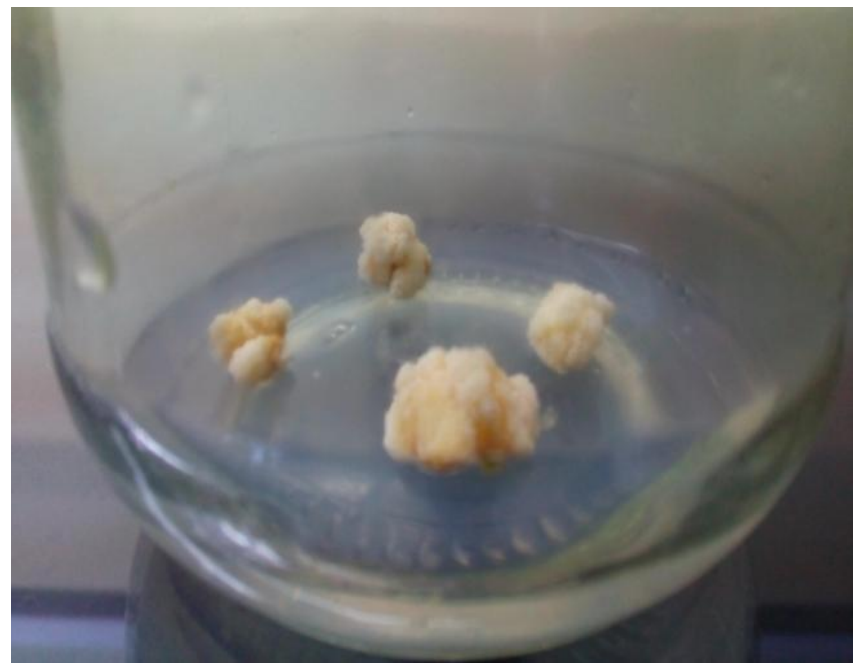

Fig. 2: Callus induction of P. missionis leaf explant.

\section{Conclusion}

An efficient and reproducible protocol for high frequency callus induction in A. monophylla and $P$.

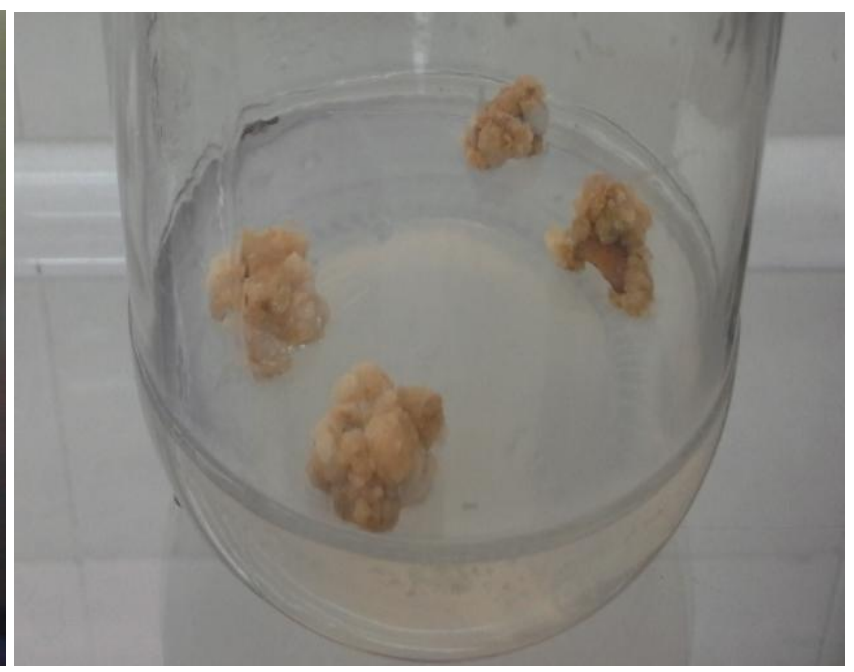

missionis were developed. The results of the present study demonstrated that MS media supplemented with varying concentration of 2,4-D showed best response for callus induction in both plants. But in P. missionis, 
2,4-D showed better percentage response, but it takes long incubation period. BA in combination with IAA showed moderate callus response within short incubation period.

\section{Conflict of interest statement}

Authors declare that they have no conflict of interest.

\section{Acknowledgement}

We are highly thankful to Dr. P.A. Mary Helen, Assistant Professor, Department of Biotechnology, Malankara Catholic College, Mariagiri for the support and full guidance to complete this research work. We are also grateful to Greenova Center for Botanical Innovation (GCBI) for their support.

\section{References}

Abdrabou, R.T., Moustafa, R.A.K., 1993. Effect of 2,4-D concentrations and two levels of sucrose on callus induction and plantlet formation in two wheat cultivars. Ann. Agric. Sci. Cairo. 1, 41-46.

Barabanova, E.A., Bannikova, V.P., Girko, V.S., 1988. Plant regeneration from cultured embryos of winter wheat. Biologiya kul'tiviruemykh kletok i biotekhnologiya, Novosibirsk, USSR 1, 110.

Bartok, T., Sagi, F., 1990. A new endosperm-supported callus induction method for wheat (Triticum aestivum L.). Cereal Research Institute, Hungary. Plant Cell, Tiss. Organ Cult. 22, 37-41.

Bourgaud, F., Gravot, A., Milesi, S., Gontier, E., 2001. Production of plant secondary metabolites: A historical perspective. Plant Sci. 161, 839-851.

George, E.F., Sherrington, P.D., 1984. Plant Propagation by Tissue Culture. Eversley, Basingstoke. Exegetics Limited, UK.
Haliloglu, K., 2006. Efficient regeneration system from wheat leaf base segments. Biol. Plantar. 50, 326-330.

Murashige, T., Skoog, F., 1962. A revised medium for rapid growth and bioassays with tobacco tissue cultures. Physiol. Plantar. 15, 473-497.

Nagata, T., Takebe, I., 1971. Plating of isolated tobacco mesophyll protoplasts on agar medium. Planta. 99, 12-20.

Neely, D., 1979. Tree wounds and wound closure. J. Arboricul. 5, 135-140.

Pandey, S.K., Ramesh, B., Gupta, P.K., 1994. Study on effect on genotype and culture medium on callus formation and plant regeneration in rice (Oryza sativa L.). Ind. J. Genet. Plant Breed. 54, 293-299.

Rashid, U., Shaukat, A., Ghulam, M.A., Najma, A., Shahid Masood, M., 2009. Establishment of an efficient callus induction and plant regeneration system in Pakistani wheat (Triticum aestivum) cultivars. Electronic J. Biotechnol. $12,3$.

Sahoo, Y., Chand, P.K., 1998. Micropropagation of Vitex negundo L. a woody aromatic medicinal shrub through high frequency of axillary shoot proliferation. Plant Cell Rep. 18, 301-307.

Savita Singh, B., Virk, G.S., Nagpal, A.K., 2011. An efficient plant regeneration protocol from callus cultures of Citrus jambhiri Lush. Physiol. Mol, Biol. Plants. 17, 161-169.

Shah, M.I., Jabeen, M., Ilahi, I., 2003. In vitro callus induction, its proliferation and regeneration in seed explants of wheat (Triticum aestivum L.) Var. Lu-26s. Pak. J. Bot. 35, 209217.

Singh, N., Meena, M.K., Patni, V., 2011. Effect of plant growth regulators, explants type and efficient plantlet regeneration protocol through callus induction in Naringi crenulata (Roxb.) Nicolson and its biochemical investigation. Afr. J. Biotechnol. 10, 17769-17777.

Steward, F.C., Mapes, M.O., Mears, K., 1958. Growth and organized development of cultured cells. II. Organization in cultures grown from freely suspended cells. Am. J. Bot. 45, 705-708.

\section{How to cite this article: \\ Jaya Sree, S., Vijayakumar, N., Suseela Gomathi, K., 2016. Effect of plant growth regulators on callus induction in Atalantia monophylla and Pamburus missionis. Int. J. Curr. Res. Biosci. Plant Biol. 3(3), 21-25. doi: http://dx.doi.org/10.20546/ijcrbp.2016.303.004}

